\title{
BIOCHEMICAL PROFILE OF CHRONIC KIDNEY DISEASE (CKD) PATIENTS IN VARIOUS AGE AND GENDER GROUP SUBJECTS VISITING KIST MEDICAL COLLEGE \& TEACHING HOSPITAL, KATHMANDU
}

\author{
YP Paudel ${ }^{1}$, S Dahal ${ }^{2}$, T Acharya ${ }^{3}$, AP Joshi ${ }^{3}$, B Shrestha ${ }^{3}$, M Khanal ${ }^{2}$ and D Kafle ${ }^{4 *}$ \\ ${ }^{1}$ Department of Clinical Biochemistry, KIST Medical College and Teaching Hospital, Imadol, Lalitpur, Nepal. \\ ${ }^{2}$ Department of Clinical Biochemistry, Nepal Medical College and Teaching Hospital, Attarkhel, Kathmandu, Nepal. \\ ${ }^{3}$ Department of Clinical Biochemistry, Nobel College, Sinamangal, Kathmandu, Nepal. \\ ${ }^{4}$ Department of Clinical Biochemistry, Chitwan Medical College, Bharatpur-10, Nepal. \\ *Correspondence to : Mr Deepak Kafle, Department of Clinical Biochemistry, Chitwan Medical College, Bharatpur-10, Chitwan, Nepal. \\ Email:deepakkafley@hotmail.com
}

\begin{abstract}
Nowadays it is observed that the chronic kidney disease (CKD) is a growing health problem worldwide and the most common illness associated with this is hypertension (HTN) and diabetes mellitus (DM). This study tries to find out illness associated with CKD and assess the renal parameters according to age and sex group. This is a cross sectional descriptive study. Diagnosed cases of Chronic Kidney Disease patients visiting at KIST Medical College from September to November 2011 are included in this study. SPSS-17 version is used for data analysis and appropriate statistical tests are done. Among 150 patients, $57 \%$ are male and $43 \%$ are female. Mean age of the study population is $48.62 \pm 18.09$ years. Level of urine protein for male is higher than female. Mean urea, creatinine, potassium, uric acid, phosphorus and protein creatinine ratio (PCR) are higher in younger age group. The result also depicts hypertension is the leading illness associated with CKD (50\%). Only $8 \%$ diabetes mellitus cases are associated with CKD followed by both of hypertension and diabetes mellitus (26\%) and $16 \%$ others. This study provides an overview of routine biochemical parameters with CKD. Hypertension is found as leading illness associated with CKD. Differences in renal parameters are found in gender and different age groups.
\end{abstract}

Key Words: Associated Illness, CKD \& Renal Function Test.

\section{INTRODUCTION}

Chronic kidney disease (CKD) is increasingly recognized as a major public health problem. Chronic Kidney disease (CKD) is defined as kidney damage or glomerular filtration rate (GFR) $<60.0 \mathrm{ml} / \mathrm{min} / 1.73 \mathrm{~m} 2$ for three months or more irrespective of the cause. ${ }^{1}$ CKD 5 is defined when GFR is $<15.0 \mathrm{ml} /$ $\min / 1.73 \mathrm{~m} 2 .{ }^{2}$ In fact CKD patients are increasing in number day by day. Nephrology service in Nepal was started by an eminent nephrologist of Nepal late Dr PR Satyal in early 1970s, but hemodialysis (HD) service in Nepal was started only in 1987 in Bir Hospital (National Academy for Medical Sciences). ${ }^{3}$

CKD can be detected via simple biochemical tests including a creatinine-based estimate of the glomerular filtration rate (GFR). ${ }^{4}$ There are different renal function parameters to indicate reduced kidney function. CKD typically increases with age and therefore there is increased risk in older adults. It is found that females are less prone to the risk of CKD. It is also seen that diabetes and hypertension are the main two causes of CKD. ${ }^{5}$

Therefore the objective of the study was to determine biochemical profile of chronic kidney disease (CKD) patients and to find out the variation of renal function test among different age and gender group and also tried to list out the illness associated with CKD visiting at KIST Medical College \& Teaching Hospital, Kathmandu, Nepal.

\section{MATERIAL AND METHODS}

This is a cross sectional study done at KIST Medical College and Teaching Hospital. The sample population is the diagnosed cases of Chronic Kidney Diseased patients who visited at KIST Medical College from September to November 2011. The biochemical parameters of renal function test in serum and urine are assessed. For Data analysis SPSS-17 version is used. Descriptive statistics, Kruskal Wallis test and independent test are used in data analysis. Approval from the Institutional Review Board was taken prior to the study.

\section{RESULTS}

The mean age of patients is $48.62 \pm 18.09$ years (range: $12-95$ ). There are $43 \%$ female and $57 \%$ male patients. Mean level of urea, creatinine, sodium and potassium are $135.25 \pm 76.06(\mathrm{mg} /$ $\mathrm{dl}), 6.21 \pm 4.31(\mathrm{mg} / \mathrm{dl}), 136.25 \pm 5.65(\mathrm{mmol} / \mathrm{L})$ and $4.83 \pm 1.06$ $(\mathrm{mmol} / \mathrm{L})$ respectively. Similarly, average level of uric acid, calcium, phosphorus, total protein, albumin and $A / G$ ratio 
are $5.96 \pm 2.22(\mathrm{mg} / \mathrm{dl}), 8.22 \pm 1.18(\mathrm{mg} / \mathrm{dl}), 6.24 \pm 2.47(\mathrm{mg} / \mathrm{dl}), 4.84 \pm 0.91(\mathrm{~g} / \mathrm{dl})$ and $2.25 \pm 0.53(\mathrm{~g} / \mathrm{dl})$ and $1.23 \pm .61$ respectively. Likewise, average urinary protein and urinary creatinine are $233.61 \pm 152.97(\mathrm{mg} / \mathrm{dl})$ and $64.71 \pm 30.72(\mathrm{mg} / \mathrm{dl})$. Average protein Creatinine ratio (PCR) is $4.28 \pm 3.86$. Hypertension (50\%) is found as main co- morbidity associated with CKD (Figure 1).

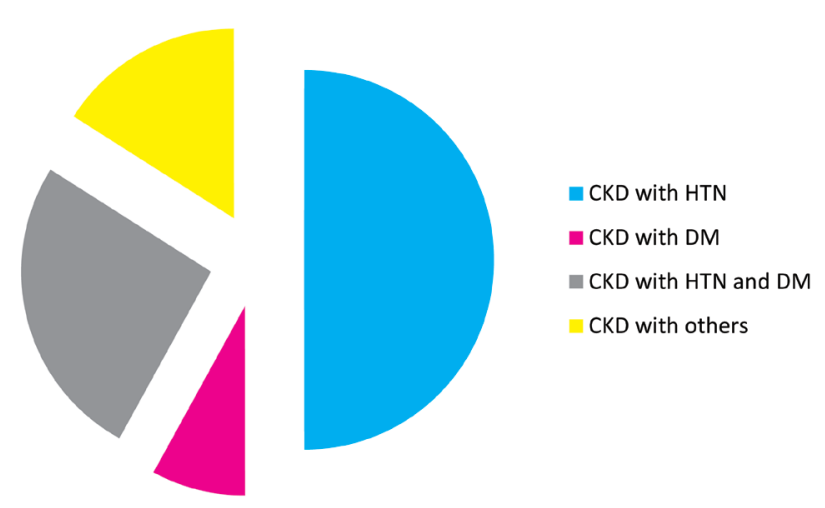

Figure 1: Co-morbidity associated with CKD

Table 1: Sex differentials in renal parameters of CKD patients

\begin{tabular}{|l|c|c|c|c|c|}
\hline \multirow{2}{*}{ Renal parameter } & \multicolumn{2}{|c|}{ Male } & \multicolumn{2}{c|}{ Female } & p \\
\cline { 2 - 5 } & Mean & SD & Mean & SD & \\
\hline Level of Urea (mg/dl) & 135.47 & 72.74 & 134.97 & 80.91 & 0.97 \\
\hline Level of Creatinine (mg/dl) & 6.27 & 4.22 & 6.13 & 4.46 & 0.84 \\
\hline Level of Sodium (mmol/L) & 136.90 & 5.20 & 135.38 & 6.14 & 0.10 \\
\hline Level of Potassium (mmol/L) & 4.73 & 1.04 & 4.97 & 1.08 & 0.18 \\
\hline Level of Uric Acid (mg/dl) & 6.03 & 2.15 & 5.88 & 2.32 & 0.68 \\
\hline Level of Calcium (mg/dl) & 8.26 & 1.18 & 8.16 & 1.19 & 0.61 \\
\hline Level of Phosphorus (mg/dl) & 6.30 & 2.41 & 6.16 & 2.56 & 0.74 \\
\hline Level of Total Protein (g/dl) & 4.79 & 0.90 & 4.92 & 0.92 & 0.38 \\
\hline Level of Albumin (g/dl) & 2.47 & 0.53 & 2.58 & 0.53 & 0.18 \\
\hline Albumin/Globulin Ratio & 1.19 & 0.57 & 1.30 & 0.67 & 0.26 \\
\hline Level of Urine Protein (mg/dl) & 66.71 & 31.92 & 62.03 & 29.07 & 0.36 \\
\hline Level of Urine Creatinine (mg/dl) & 157.77 & 220.02 & 146.41 & 0.35 \\
\hline PCR & & 3.19 & 4.41 & 4.64 & 0.73 \\
\hline
\end{tabular}

None of the renal parameters showed significant sex differentials. Level of urine protein for male is higher than female but the difference is not significant. 
Table 2: Age differentials in renal parameters of CKD patients

\begin{tabular}{|c|c|c|c|c|c|c|c|c|c|c|c|c|c|}
\hline Age group & \multicolumn{3}{|c|}{$<20(n=7)$} & \multicolumn{3}{|c|}{$20-40(n=44)$} & \multicolumn{3}{|c|}{$40-60(n=51)$} & \multicolumn{3}{|c|}{$>60(n=48)$} & \multirow[t]{2}{*}{$\mathbf{P}$} \\
\hline Parameter & Mean & SD & $\mathrm{Md}$ & Mean & SD & $\mathrm{Md}$ & Mean & SD & $\mathrm{Md}$ & Mean & $\mathrm{SD}$ & $\mathrm{Md}$ & \\
\hline Urea & 191.1 & 68.8 & 182.0 & 134.7 & 77.6 & 108.0 & 134.7 & 77.6 & 123.0 & 69.3 & 6.7 & 118.5 & 0.20 \\
\hline Creatinine & 8.4 & 5.9 & 7.9 & 6.8 & 4.3 & 6.6 & 6.2 & 4.1 & 5.5 & 5.2 & 4.1 & 3.8 & 0.11 \\
\hline Sodium & 134.6 & 5.3 & 135.0 & 134.3 & 5.7 & 134.0 & 137.4 & 5.6 & 138.0 & 137.1 & 5.2 & 138.0 & 0.04 \\
\hline Potassium & 5.4 & 1.0 & 5.8 & 4.9 & 1.0 & 4.7 & 4.8 & 1.0 & 4.7 & 4.8 & 1.2 & 4.6 & 0.29 \\
\hline Uric acid & 7.0 & 3.1 & 6.8 & 6.1 & 2.6 & 5.2 & 6.1 & 2.6 & 5.4 & 6.0 & 2.1 & 5.7 & 0.69 \\
\hline Calcium & 8.1 & 1.2 & 7.7 & 8.1 & 1.3 & 7.9 & 8.4 & 1.2 & 8.4 & 8.2 & 1.1 & 8.2 & 0.59 \\
\hline Phosphorus & 8.3 & 2.7 & 8.0 & 6.3 & 2.5 & 6.5 & 6.5 & 2.7 & 5.9 & 5.6 & 2.0 & 5.3 & 0.07 \\
\hline Total Protein & 4.9 & 1.0 & 4.8 & 4.9 & 0.9 & 4.9 & 5.0 & 1.0 & 5.0 & 4.7 & 0.8 & 4.6 & 0.36 \\
\hline Albumin & 2.5 & 0.6 & 2.4 & 2.5 & 0.5 & 2.5 & 2.6 & 0.6 & 2.5 & 2.5 & 0.4 & 2.4 & 0.97 \\
\hline $\mathrm{A} / \mathrm{G}$ ratio & 1.1 & 0.5 & 0.9 & 1.2 & 0.6 & 1.1 & 1.2 & 0.6 & 1.1 & 1.3 & 0.6 & 1.2 & 0.28 \\
\hline PCR & 6.1 & 4.7 & 5.4 & 4.1 & 3.2 & 3.3 & 4.6 & 4.6 & 4.2 & 3.8 & 3.4 & 3.3 & 0.43 \\
\hline
\end{tabular}

The mean average level of renal parameters is statistically less significant i.e. no difference according to age and sex i.e. p-value was $>0.05$ but there is significant difference in the mean average level of sodium according to age group i.e. $p=0.042$. Mean urea, creatinine, potassium, uric acid, phosphorus and PCR are higher in younger age group but differences are not significant. The mean value of albumin is also found almost same in all age groups. Calcium, total protein, and A/G ratio differences in various age groups are very minimal.

\section{DISCUSSION}

Several studies concur that chronic kidney disease typically increases with age. ${ }^{6,8}$ Older adults are, therefore, at increased risk for chronic kidney disease. ${ }^{9}$ It is found that the female gender is associated with slower progression of chronic kidney disease. It also supports the present study in which $43 \%$ of the total patients are female. In this study we found that HTN is the leading illness associated with CKD $(50 \%)$, followed by DM $(8 \%)$, both of HTN and DM (26\%), others (16\%) and which is almost similar to the study carried out by Chhetri et.al., 10 where studies from the neighbouring countries like India showed DM and HTN as leading causes. ${ }^{10,12}$ The two main causes of CKD, diabetes and hypertension, account for as much as $70 \%$ of all new cases. ${ }^{13}$

Mean average level of the urea, creatinine, sodium, potassium is found to be $135.25 \pm 76.067 \mathrm{mg} / \mathrm{dl}, 6.2 \pm 4.3 \mathrm{mg} / \mathrm{dl}, 136.25 \pm 5.65$ $\mathrm{mmol} / \mathrm{L}, 4.8 \pm 1.06 \mathrm{mmol} / \mathrm{L}$ respectively, similar parameter done by Chhetri et.al., ${ }^{14}$ found level of urea, creatinine, sodium, potassium $209.76 \mathrm{mg} / \mathrm{dl}, 10.95 \mathrm{mg} / \mathrm{dl}, 129.27 \mathrm{mmol} / \mathrm{L}, 4.8$ $\mathrm{mmol} / \mathrm{L}$ respectively. Similarly study carried out by Bhan et.al. ${ }^{15}$ found level of creatinine, potassium was $1.3 \pm 0.4(\mathrm{mg} / \mathrm{dl})$, $4.2 \pm 0.3(\mathrm{mmol} / \mathrm{L})$ respectively and Shah et.al., ${ }^{16}$ found level of creatinine $1.6 \pm 0.7 \mathrm{mg} / \mathrm{dl}$. This study showed the mean level of urea, creatinine lower than study carried out by Chhetri et.al.14 and level of creatinine higher than study carried out by Bhan et. al.15and Shah et.al. ${ }^{16}$ In contrast to the study by Chhetri et.al., ${ }^{14}$, the result from this study depict higher sodium level. Similarly the level of potassium is found to be higher than study carried out by Bhan et.al. ${ }^{15}$

In this study the mean average level of uric acid, calcium, phosphorus, albumin is $5.96 \pm 2.21 \mathrm{mg} / \mathrm{dl}, 8.21 \pm 1.18 \mathrm{mg} / \mathrm{dl}$, $6.24 \pm 2.27 \mathrm{mg} / \mathrm{dl}, 2.52 \pm 0.53 \mathrm{~g} / \mathrm{dl}$ respectively, similar parameter carried out by Shah et.al.,16 showed that level of uric acid, calcium, phosphorus, albumin was $7.0 \pm 2.3,9.4 \pm 0.5,3.6 \pm$ $0.6 \mathrm{mg} / \mathrm{dl}, 4.1 \pm 0.5 \mathrm{~g} / \mathrm{dl}$ respectively and study carried out by Juan et.al. ${ }^{17}$ showed that mean level of calcium, phosphorus, and albumin was $9.4 \pm 0.6,4.04 \pm 1.1 \mathrm{mg} / \mathrm{dl}, 4.04 \pm 0.31 \mathrm{~g} / \mathrm{dl}$ respectively and study carried out by Bhan et.al 15 showed that level of calcium, phosphorus was $9.3 \pm 0.4,3.2 \pm 0.5 \mathrm{mg} /$ dl respectively. This study shows that mean level of uric acid, calcium is found lower, level of phosphorus is higher and level of albumin is lower than study carried out by Shah et.al., ${ }^{16}$, Juan et.al., ${ }^{17}$ Bhan et.al., ${ }^{15}$ respectively. In both the National Health 
and Nutrition Examination Survey (NHANES) and Kidney Early Evaluation Program (KEEP) studies, the prevalence of $\mathrm{CKD}$, defined as a serum creatinine level $>1.3 \mathrm{mg} / \mathrm{dL}$ in women and $>1.5 \mathrm{mg} / \mathrm{dL}$ in men, rise rapidly in those aged 60 years and over (Robinson, 2006). ${ }^{18}$ A study carried out by Bhan et.al., ${ }^{15}$ on the diagnosis and management of mineral metabolism in CKD concluded that disorder of the mineral metabolism in CKD is common, under diagnosed and under treated.

In this study mean level of total protein is found to be $4.84 \pm 0.91 \mathrm{~g} /$ $\mathrm{dl}$, mean level of albumin is found to be $2.25 \pm 0.53 \mathrm{~g} / \mathrm{dl}$, Mean level of $\mathrm{A} / \mathrm{G}$ ratio is found to be $1.23 \pm .61$, mean level of urinary protein is found to be $233.61 \pm 152.97 \mathrm{mg} / \mathrm{dl}$ and median is 195 , mean level of urinary creatinine is found to be $64.71 \pm 30.72 \mathrm{mg} /$ $\mathrm{dl}$, mean level of PCR is found to be $4.28 \pm 3.86$.

Study done by Juan et. al., ${ }^{17}$ showed mean level of calcium, phosphorus is $8.20 \mathrm{mg} / \mathrm{dl}$ and $5.75 \mathrm{mg} / \mathrm{dl}$ which are similar to our study. Study done by Alberto et, al., ${ }^{19}$ showed that serum creatinine, serum phosphorus and serum albumin is $2.4 \mathrm{mg} / \mathrm{dl}$, $3.7 \mathrm{mg} / \mathrm{dl}$ and $3.9 \mathrm{~g} / \mathrm{dl}$ respectively. Mean level of calcium is 9.3 $\mathrm{mg} / \mathrm{dl}$, which is similar to our study.

\section{CONCLUSION}

Hypertension is the main co morbidity associated with CKD, the second one being HTN and DM together. Difference in the mean average level of sodium according to age group is found to be statistically significant. Albumin is found higher in male and other renal parameters like urea, creatinine, potassium, uric acid, phosphorus and PCR found to be higher in younger groups.

\section{REFERENCES}

1. K/DOQI clinical practice guidelines for chronic kidney disease: evaluation, classification, and stratification. Amer J Kidney Dis 2002; 39 (2 Suppl 1): S1-266.

2. Levey AS, Eckardt KU, Tsukamoto Y et al. Definition and classification of chronic kidney disease: a position statement from Kidney Disease: Improving Global Outcomes (KDIGO). Kidney Int'1 2005; 67: 2089-100.

3. Chhetri PK, Satyal PR, Kafle R, Khakurel S, Pradhan BR. Experience of hemodialysis in Bir hospital. Nepal Med Coll J 1999; 1: 99-101.

4. Levey AS, Bosch JP, Lewis JB et al. Modification of Diet in Renal Disease Study Group. Amore accuratemethod to estimate glomerular filtration rate from serum creatinine: a new prediction equation. Ann Intern Med 1999; 130: 461-470.

5. De Zeeuw D, Hillege HL, de Jong PE. The kidney, a cardiovascular risk marker, and a new target for therapy. Kidney Int Suppl 2005;68(Suppl 98s): S25-S29.

6. Chen J, Muntner P, Hamm L, Jones D, Batuman V, Fonseca $\mathrm{V}$ et. al. The metabolic syndrome and chronic kidney disease in U.S. adults. Annals of Internal Medicine. 2004; 140(3): 167174.

7. Coresh J, Astor B, Greene T, Eknoyan G, Levey A. Prevalence of chronic kidney disease and decreased kidney function in the adult U.S. population: Third National Health and Nutrition Examination Survey. American Journal Kidney Disease. 2003; 41(1): 1-12.

8. Levey A, Coresh J, Balk A, Kausz A, Levin M, Steffes $\mathrm{R}$, et al. Diagnosis and evaluation of patients with chronic kidney disease: Recommendations from the National Kidney Foundation. Annals of Internal Medicine 2003; 139(2): 1-36.

9. Duncan J, Levin A. Sex hemoglobin and kidney disease: New perspectives. European Journal of Clinical Investigation 2005; 35(3): 52-7.

10. Chhetri PK, Manandhar DN, Tiwari R, Lamlichhane S. In-centre haemodialysis for end stage kidney disease at Nepal Medical College Teacing Hospital. Nepal Med Coll J 2009; 11(1): 61-63.

11. Mittal S, Kher V, Gulati S. Chronic renal failure in India. Renal failure 1997; 19:763-70.

12. Dash SC, Agrawal SK. Incidence of chronic kidney disease in India. Nephro Dial Transplant 2006; 21: 232-3.

13. Coresh J, Selvin E, Stevens L, Manzi J, Kusek J, Eggers P, et. al. Prevalence of chronic kidney disease in the United States. The Journal of the American Medical Association 2007; 298(17): 2038-47.

14. Chhetri PK, Manandhar DN, Bhattarai SP, Pahari LR, Shrestha R. Chronic kidney disease on hemodialysis in Nepal Medical College Teaching Hospital. Department of Medicine, Nepal Medical College Teaching Hospital, Jorpati, Kathmandu, Nepal. Nepal Med Coll J 2008;10(1):8-10.

15. Bhan I, Dubey A, Wolf M. Diagnosis and Management of Mineral Metabolism in CKD. J Gen Intern Med 2010; 25(7):710-6.

16. Shah NR, Dumler F. Hypoalbuminaemia - A Marker of Cardiovascular Disease in Patients with Chronic Kidney Disease Stages II - IV. Int J Med Sci 2008; 5(6):366-370.

17. Juan F, Navarro G, C MF, Mercedes M, Haridian H, Javier GC. Mineral Metabolism and Inflammation in Chronic Kidney Disease Patients: A Cross-Sectional Study. J Am Soc Nephrol 2009; 4: 1646-1654.

18. Robinson BE. Epidemiology of Chronic Kidney Disease and Anaemia. Journal of American Medical Directors Association 2006; 7: S3-S6.

19. Alberto MC, José LG, José MP, Fernando DA, Aleix C, José L, Juan FN, Rafael M, et al. Baseline characteristics of patients with chronic kidney disease stage 3 and stage 4 in spain: the MERENA observational cohort study. BMC Nephrology $2011 ; 12: 53$. 